\title{
The Levelized Cost of Energy (LCOE) of wave energy using GIS based analysis: The case study of Portugal
}

\author{
Laura Castro-Santos*, Geuffer Prado Garcia, Ana Estanqueiro, Paulo A.P.S. Justino \\ National Energy Laboratory (LNEG), Solar, Wind and Ocean Energy Unit (UESEO), Estrada do Paço do Lumiar, 22, 1649-038 Lisbon, Portugal
}

\section{A R T I C L E I N F O}

Article history:

Received 4 July 2014

Received in revised form 1 September 2014

Accepted 13 September 2014

\section{Keywords:}

Wave power

GIS

Economic atlas

Ocean renewable energy

\begin{abstract}
A B S T R A C T
The main objective of this paper is to establish an economic modelling of wave energy through a Geographical Information System (GIS). Furthermore, this method has been tested for the particular case of the Portuguese coast. It determines the best sea areas to install wave energy converters in this region, using spatial analysis of the Levelized Cost of Energy (LCOE). Several economic parameters, as capital or O\&M costs, have been considered. In addition, a sensitivity analysis has been performed by varying the discount rate in three different scenarios. Several types of physical restrictions have been taken into account: bathymetry, submarine electrical cables, seabed geology, environmental conditions, protected areas in terms of heritage, navigation areas, seismic fault lines, etc. Spatial operations have been carried out to complete the procedure, using Model Builder of GIS software. Results indicate the most suitable areas in economic terms in Portugal to install wave energy devices.
\end{abstract}

다 2014 Published by Elsevier Ltd.

\section{Introduction}

Nowadays, one of the most important problems all over the world is generating enough clean energy to guarantee human consumption without harming the environment [1]. In this context, offshore renewable energies can help to achieve this purpose.

Portugal has many kilometres of coast which could be exploited in terms of wave energy [2]. Furthermore, the Portuguese government is aiming to achieve $60 \%$ of produced electricity by RES in 2020, following the European path. Nevertheless, renewable resources for electricity production should be diversified to achieve this objective.

According to different renewable resources for electricity production, marine energies, such as wave, tide or offshore wind, have a large potential of application in Portugal [3-5]. In fact, over the last 30 years, Portugal has been on the front edge of marine renewable energy field. In this sense, several examples could be quoted: wave power plant of $400 \mathrm{~kW}$ was connected to the grid in 1999, in Pico (Açores) [6]; the research wave power plant, Pelamis [7,8], with 2.25 MW, has been in operation in 2009 in Aguçadoura [9]; or the second floating offshore wind turbine in the world, WindFloat [10], which has also been installed in 2009 in Aguçadoura.

In the last decade, many research projects of wave energy converters (WECs) have been developed all over the world

\footnotetext{
* Corresponding author.

E-mail address: laura.castro.santos@udc.es (L. Castro-Santos).
}

[14,15], especially in Europe. They can be used to obtain some of the huge amounts of energy which can theoretically be exploited from the oceans [16,17]. Most of the designs convert the wave energy to electrical energy $[18,19]$, but wave energy can also be used for the desalination of salt water by reverse osmosis, which has vital importance for many societies and countries situated in arid climates [20].

Wave energy development is being considered by the Portuguese Government for the accomplishment of its goal respecting renewable energy sources [5]. One example is the pilot zone in Pedro de Moel (Decree-Law 5/2008), created in early 2008 [21].

Although waves resource has been previously studied in several papers [11-13], the economic path [22] is the most important perspective for developers [23]. In this context, the aim of this article will be to determine the best economic areas in Portugal where wave energy can be developed. In this sense, the economic index of the Levelized Cost of Energy (LCOE) will be analysed. In addition, a sensitivity analysis will be performed by varying the discount rate in three different scenarios. Furthermore, several types of physical restrictions will be taken into account: bathymetry, submarine electrical cables, seabed geology, environmental conditions, protected areas in terms of heritage, navigation areas, seismic fault lines, etc. Spatial operations have been carried out to complete the procedure, using Model Builder of GIS (Geographic Information System) software [24]. Results will indicate the most suitable areas in economic terms in Portugal to install wave energy devices. 